\title{
原著論文
}

口腔水分計（モイスチャーチェッカー・ムーカス ${ }^{\circledR}$ ) の有用性

高橋史 小司 利昭森田修己

\section{The Usefulness of an Oral Moisture Checking Device (Moisture Checker for Mucus ${ }^{\circledR}$ )}

Takahashi Fumi, Koji Toshiaki and Morita Osami

\section{歯科補経学的意義}

近年の高齢社会においては口腔乾燥を訴える患者が増加しており，日常臨床においても患者の口腔乾燥状態を把握 しておくことが必要である， 口腔水分計は，粘膜上皮内に含まれる水分量を 2 秒で測定することが可能である．本 研究では, その有用性について検討し, 測定時の接触圧をコントロールすることにより測定誤差は $1 \%$ 以下となり, 健常成人の水分量が一定の範囲内となることから， 口胿水分計は有用な機器であるとの示唆を得た.

抄 録

目的：簡便にチェアサイドで行えるロ腔乾燥の評価法である口腔水分計の有用性について検討すること を目的とした。

方法：口腔水分計に影響を与える因子の検討は被験者 16 名（平均年齢 27.5 歳），健常成人の水分量の 測定は被験者 32 名（平均年齢 24.4 歳）を対象とした．水分計の測定值に影響を与える因子のうち，接 触圧については，接触圧をメーカー指示である約 $200 \mathrm{~g}$ にコントロールするためのストッパーを付与し たときと，付与しないときの水分量を比較した，センサーカバーについては，専用カバーを取り換えて 使用したときの水分量を比較した．測定器については， 2 個の測定器を使用したときの水分量を比較し た。健常成人の水分量の測定は，舌粘膜および煩粘膜において行った.

結果：接触圧については，ストッパーを付与したときのほうが付与しないときよりも $0.2 \sim 0.3 \%$ 低い 值となった。 センサーカバーについては，カバーを取り換えると $0.5 \sim 0.8 \%$ 值が異なった. 測定器に ついては, 個々の測定器の間に有意差が認められなかった。健常成人における水分量は, 舌粘膜では平 均值 $30.6 \pm 0.3 \% ，$ 煩粘膜では $30.9 \pm 0.3 \%$ であった.

結論：口腔水分計は，測定時の接触圧を適切にコントロールすることにより測定誤差は $1 \%$ 以下とな $\eta$, また, 健常成人の水分量が一定の範囲内となることから, 安静時の口腔乾燥状態を検查するのに有 用な機器であることが示唆された。

\section{和文キーワード}

口腔乾燥, 口腔水分計, 有用性

日本歯科大学新潟歯学部歯科補緅学第 3 講座

Department of Complete Denture, The Nippon Dental University School of Dentistry at Niigata

受付: 2004 年 8 月 2 日/受理 : 2005 年 1 月 31 日

Received on August 2, 2004/Accepted on January 31, 2005 


\section{I. 緒 言}

口腔乾燥症 $(\text { Xerostomia })^{1)}$ は, 唾液分泌量の減少 によって口腔内が乾燥し，口腔，咽頭などにさまざま

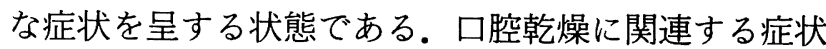
としては, 口腔乾燥感や唾液のねばねば感，分泌低下 による口腔の違和感, 舌痛症や口腔粘膜の疼痛, 義歯 の不適合や疼痛，義歯性潰瘍の頻発，アフ夕性口内炎 や粘膜潰瘍, 咀嚼障害, 嚥下障害, 味覚障害, 構音障 害などがあり2)，これらの要因を考慮した診断，治 療, ケアが重要となる。

近年の高齢社会においては，口腔乾燥を訴える患者 が増加しており, 口腔乾燥の自覚症状に関する調査研 究によると, 65 歳以上の高齢者のうち $56.1 \%$ が口腔 乾燥感を自覚しており, 病院などへ入院していない高 齢者に限っても $51.1 \%$ と高い頻度である ${ }^{2)}$. 日常臨 床においても, 患者の口腔乾燥状態を把握しておくこ とが必要であり，口腔機能や全身状態に依存せずチェ アサイドで簡便に行えるロ腔乾燥の評価法が望まれ る.これまでの口腔乾燥症の診断に対する検査は，ガ ムテストやサクソンテスト 3など，咀嚼刺激による唾 液分泌量評価がほとんどであった。しかし，一般にみ られる口腔乾燥患者の多くは，安静時唾液の分泌量低 下と関連していることが多い4). したがって，高齢者 に対しても応用可能な口腔乾燥症の評価としては，自 賞症状，臨床診断，安静時の唾液分泌状態，粘膜湿潤 度，唾液物性の評価などが有用である5.

粘膜湿潤度の検査法としては，口腔水分計による水 分量の測定がある. 口腔水分計（モイスチャーチェッ カー・ムーカス ${ }^{\circledR}, \mathrm{MY} 01$ ，スカラ）は，センサー部 に専用のセンサーカバーを装着して口腔粘膜に接触さ せることにより，粘膜上皮内に含まれる水分量を 2 秒 で測定することが可能である，測定值の低下は，湿潤 度低下や粘膜保湿度の低下を意味しており，治療や対 症療法を必要とする ${ }^{6}$ とされているが，実際には口腔 水分計による測定法については新しい測定器のため不 明な点が多い.

そこで本研究では，口腔水分計の測定値に影響を与 えると考えられる接触圧，センサーカバーおよび測定 器について検討し, さらに, 健常成人の水分量の分布 範囲を調べることにより，口腔水分計の有用性につい
て検討することを目的とした。

\section{II. 研究方法}

\section{1. 被験者}

口腔水分計の測定值に影響を与える因子の検討は, 年齢 25〜30 歳（平均年齢 27.5 歳）の男性 11 名, 女 性 5 名, 計 16 名を対象にして行った。 また, 健常成 人の口腔水分量の測定は，年齢 $22 \sim 29$ 歳（平均年齢 24.4 歳）の男性 25 名, 女性 7 名, 計 32 名を対象に して行った。いずれの被験者も，本研究の主旨を説明 し同意の得られた，自覚的に口腔乾燥を認めず，他覚 的にも唾液粘性化の六進や唾液量の減少を認めない健 常成人である。なお，本研究は，日本歯科大学新潟歯 学部倫理委員会の承認を得ている（受付番号 49).

\section{2. 方法}

1）口腔水分計の測定値に影響を与える因子の検討 口腔水分計の測定值に影響を与える因子の検討は, 接触圧, センサーカバーおよび測定器について行っ た。腔水分計による測定は, 専用のセンサーカバー を装着し，センサー部を測定部位に垂直に圧接して 行った．測定部位は，口腔乾燥感の主訴として多い部 位であることと測定が容易であることから，呫粘膜 （舌先端から約 $10 \mathrm{~mm}$ の舌背部）および煩粘膜（口角 部から内側に約 $10 \mathrm{~mm}$ の部位）とした7). 舌粘膜の 測定は舌を突出した状態で行い，煩粘膜の場合は軽く 外側から指で保持して測定を行った（図 1)。なお, 測定は 5 分間の安静の後に行い, 被験者には測定直前 に口腔内の残留唾液を嚥下するよう指示した．測定 は, 各因子の各条件に従って 5 回繰り返し行い, 平均 值を算出した。

\section{(1) 接触圧}

口腔水分計の測定は, 専用カバーを装着したセン サー先端を約 $200 \mathrm{~g}$ で圧接しながら行う7). 接触圧に ついては，測定時の接触圧を，メーカー指示である約 $200 \mathrm{~g}$ にコントロールするためのストッパーを試作 し，口腔水分計にストッパーを付与したときと，付与 しないときの水分量の平均值を比較した， 口腔水分計 の柄は，センサー部分に圧力がかかるとわずかにしな るが，約 $200 \mathrm{~g}$ の圧力をかけてしなったときに，柄の 上面が接触するようなストッパーを口腔水分計に取り 


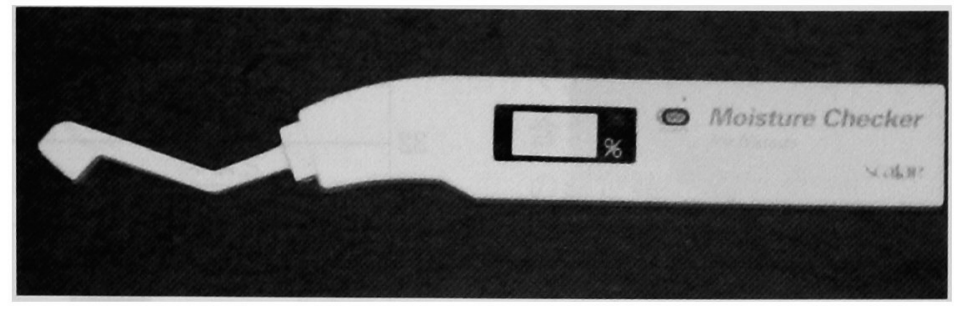

$\mathrm{a}$

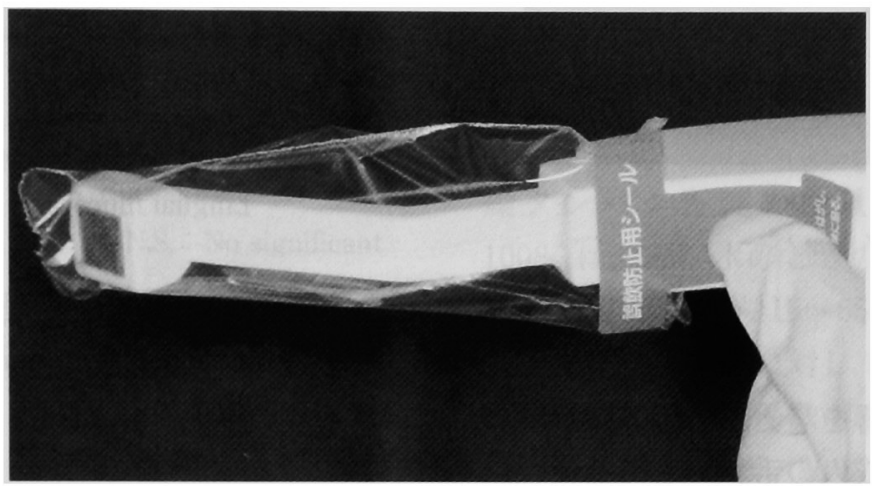

b
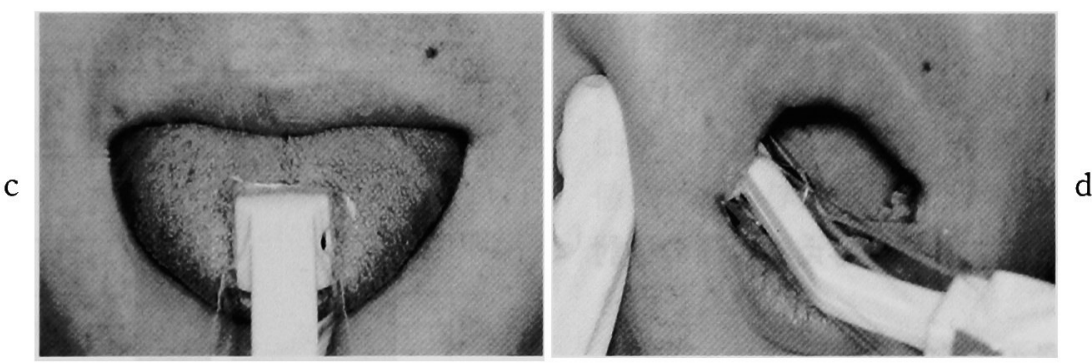

図 1 a : Oral moisture checking device, b : Fitting of the sensor cover, c: Measurement at lingual mucosa, $d:$ Measurement at buccal mucosa $\mathrm{a}$ ：口腔水分計, $\mathrm{b}$ ：センサーカバーの装着, $\mathrm{c}$ ：舌粘膜の測定, $d ：$ 煩粘膜の測定

付け，試作ストッパーとした（図 2)。また，約 $200 \mathrm{~g}$ の状態とはセンサーの柄がわずかにしなり始める程度 である7ため，ストッパーを付与しないときの圧力 は,これを目安とした。

(2) センサーカバー

専用のセンサーカバーは 1 回ごとの使い捨てであ り，1袋 20 枚入りである。測定器は 2 個（以下，測 定器 1 および 2) 使用し, 被験者を測定器 1 を使用す る者と測定器 2 を使用する者に分けた。被験者 1 人に 対し，1つの測定器に試作ストッパーを付与し，カ バー2 枚を取り換えて使用して測定を行った. 2 枚の カバーを使用したときの測定值にはバラツキがあるた め, カバーを取り換える前後の測定值を比較して, 測 定值が小さくなったほうを $\mathrm{Ax}$ (以下，カバーAx), 大きくなったほうを $\mathrm{Bx}$ (以下，カバーBx）とし，
$\mathrm{Ax}$ のときの水分量の平均值と $\mathrm{Bx}$ のときの水分量の 平均值を比較した。

(3) 測定器

測定器については, 試作ストッパーを付与した 2 個 の測定器（測定器 1 および 2) を使用したときの水分量 の平均值を比較した. 同一の被験者に 2 個の測定器を ランダムな順に使用し, カバー1 枚をつけかえて使用し て測定を行った。 カバーは被験者ごとに取り換えた。

2）健常成人の口腔水分量の測定

健常成人の口腔水分量の測定は, 口腔水分計に試作 ストッパーを付与し, カバーはおのおの異なるものを 装着して行った。測定は, 舌粘膜および頓粘膜におい て繰り返し 5 回行い, 平均値を算出した。また，舌粘 膜と煩粘膜の水分量の平均值を比較した。 


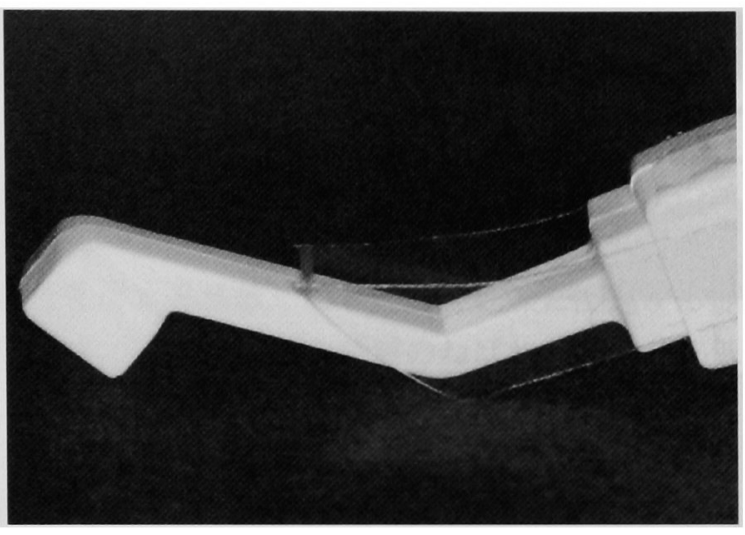

図 2 Trial stopper 試作ストッパー

\section{3. 分析方法}

口腔水分計の測定值に影響を与える各因子における 各条件の比較, および健常成人の舌粘膜と頓粘膜の口 腔水分量の比較は, 対応のある $\mathrm{t}$ 検定および Wilcoxon 検定を用いて行った。

\section{III. 結 果}

\section{1. 口腔水分計の測定值に影響を与える因子の検討}

1）接触圧

舌粘膜における水分量の平均値は, 試作ストッパー を付与したときでは $29.9 \pm 0.7 \%$ ，付与しないときで は $30.2 \pm 0.7 \%$ であった。煩粘膜では，試作ストッ パーを付与したときでは $30.1 \pm 0.4 \%$, 付与しないと

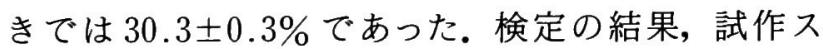
トッパーを付与したときと，付与しないときの測定値 の間には，舌粘膜では危険率 1\%で，煩粘膜では危険 率 5\% で有意差が認められ，ストッパーを付与したと きのほうが，付与しないときよりも $0.2 〜 0.3 \%$ 低い 值となった（図 3 ).

2) センサーカバー

舌粘膜における水分量の平均值は, カバー $\mathrm{Ax}$ のと きには $29.5 \pm 0.8 \%$ ，カバーBxのときには $30.2 \pm$ $0.5 \%$ であった。頓粘膜では，カバーAxのときには $29.9 \pm 0.4 \%$ ，カバーBxのとには $30.4 \pm 0.2 \%$ で あった。検定の結果, $\mathrm{Ax}$ のとき水分量の平均値と $\mathrm{Bx}$ のときの水分量の平均值の間には，危険率 $1 \%$ で 有意差が認められ，0.5〜0.8\% 值が異なった（図 4).

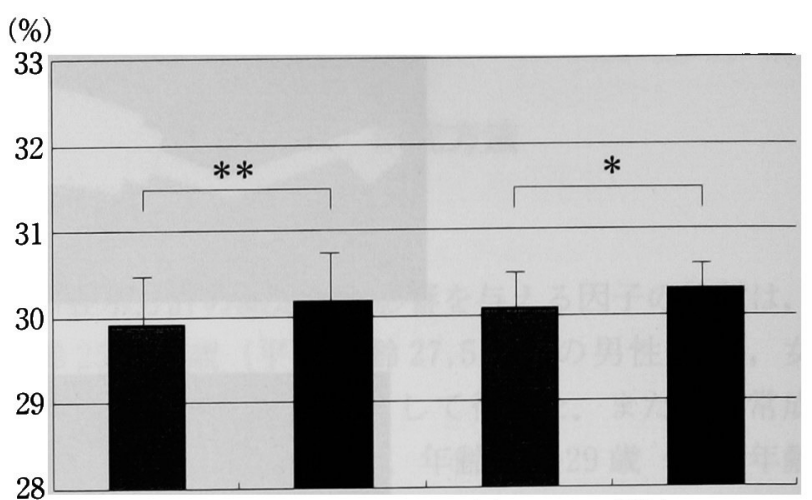

With stopper Without stopper With stopper Without stopper Lingual mucosa

Buccal mucosa

$* *: \mathrm{p}<0.01, *: \mathrm{p}<0.05$

図 3 Measured values using the oral moisture checking device (Difference in measuring pressure) 口腔水分計の測定值（接触圧による比較）

(\%)

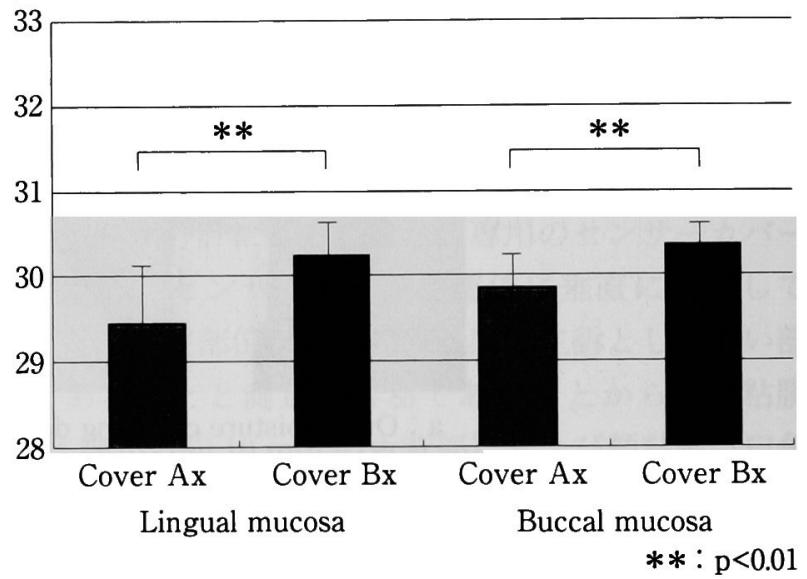

図 4 Measured values using the oral moisture checking device (Difference in sensor covers) 口腔水分計の測定值（センサーカバーによる比較）

\section{3） 測定器}

舌粘膜における水分量の平均值は, 測定器 1 を使用 したときでは $29.9 \pm 0.6 \%$, 測定器 2 を使用したとき では $30.1 \pm 0.6 \%$ であった，煩粘膜では，測定器 1 を 使用したときでは $30.0 \pm 0.6 \%$, 測定器 2 を使用した ときでは $30.1 \pm 0.5 \%$ であった，検定の結果，個々の 測定器による測定值の間には, 有意差が認められな かった（図 5).

\section{2. 健常成人の口腔水分量の測定}

健常成人における水分量は舌粘膜では平均値 
(\%)

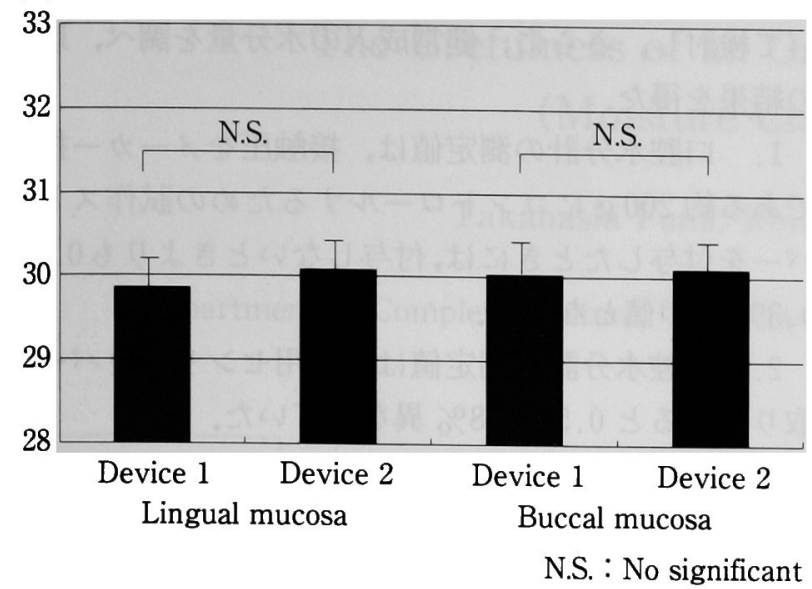

図 5 Measured values using the oral moisture checking device (Difference in devices) 口腔水分計の測定值（測定器による比較）

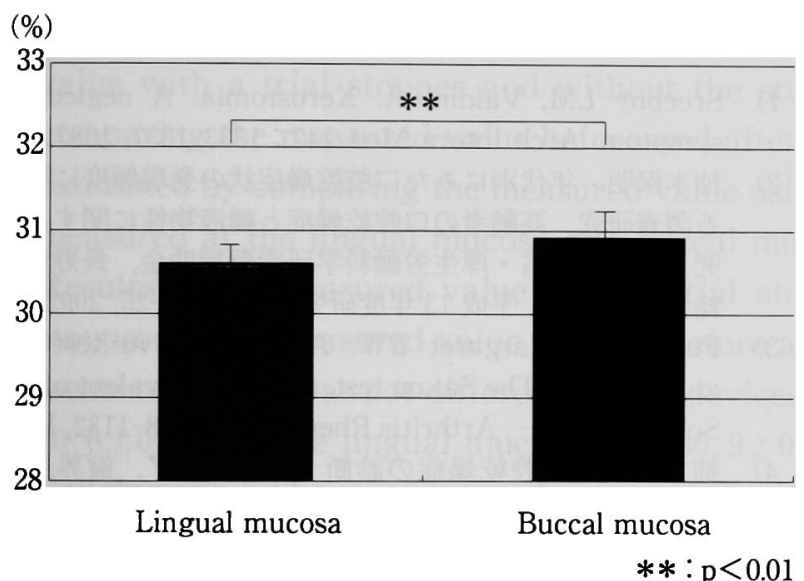

园 6 Moisture of sound adults 健常成人の水分量

$30.6 \pm 0.3 \%$ ，煩粘膜では $30.9 \pm 0.3 \%$ であった。ま た, 検定の結果, 舌粘膜と煩粘膜の水分量の間には, 危険率 $1 \%$ で有意差が認められ, 舌粘膜のほうが煩粘 膜よりも0.3〜0.4\% 低い值となった（図 6).

\section{IV. 考 察}

口腔機能や全身状態に依存せずに粘膜上皮内に含ま れる水分量を 2 秒で測定することが可能な口腔水分計 は, すでに広く使用されている肌水分計のセンサーを 応用し, 口腔用として改良したものである. 口腔水分 計の原理は, メーカーの意見では, 粘膜上皮内の水分 量を静電容量として測定することによるということで
ある. 水の誘電率はほかの物質と比べてきわめて高 く，相手の物質の誘電率を測定することにより，水が 含まれている割合がわかるため, 口腔水分計は誘電率 の測定結果から静電容量を算出し, 水分量を測ってい る. 測定対象は, センサー部を当てた部分から下の約 $1 \mathrm{~cm}^{2}$, 深さ数十 $\mu$ の上皮層である. 口腔水分計の表 示值（\%）は，医療用の特殊なタンパク質膜を標準サ ンプルとして, そのサンプルの重量水分量を基準と し, 水分の含有率で表示されている. 重量法による水 分率の定義は, 水分率 $=\mathrm{B} \div(\mathrm{A}+\mathrm{B}) \times 100 \%(\mathrm{~A}$ : 乾 燥タンパク質膜の重量, $\mathrm{B}$ : 水の重量) であり, $100 \%$ は全部が水のときの状態を表す。ただし，水分 計の測定範囲は約 15〜 65\% である. 表示值の信頼性 は, 標準サンプルに対して, 乾燥重量法の\%と水分計 の測定値との相関係数が 0.98 となっている.

水分量の目安は，30\% 以上がほほ正常，29～30\% が境界領域，27〜 29\% が唾液分泌低下，25〜 27\% が 中程度の口腔乾燥, $25 \%$ 以下が重度の口腔乾燥とさ れている ${ }^{8)}$. 本研究では, 安静時の口腔乾燥状態を評 価するのに有用と考えられる，この口腔水分計の測定 值に影響を与える因子の検討および健常成人の口腔水 分量の測定を行い, 口腔水分計の有用性について検討 を行った。

口腔水分計の測定值に影響を与える因子について, 接触圧は口腔水分計に試作ストッパーを付与しないと, 付与したときょりも $0.2 \sim 0.3 \%$ 高い值となることが 明らかとなった. 水分量の正常值と唾液分泌低下の值 との間の差は $3 \%$ であるため, 試作ストッパーを付与 しないと 1 割の誤差を生じる可能性を示している. 測 定結果は測定時の圧力に左右されやすく6), メーカー では測定圧に比例して測定值が大きくなる傾向がある ことを認識しているが, 根拠はいまだ不明である。し たがって, この結果は, 試作ストッパーを付与しない ときに接触圧が大きくなったことによるものと考えら れる. 試作ストッパーを付与しないときの接触圧の大 小には個人差があるが, 一定の条件下で測定を行うた めには試作ストッパーを付与して接触圧をメーカー指 示である約 $200 \mathrm{~g}$ にコントロールしたうえで測定を行 うことが望ましいと思われる. 本研究での測定は, 口 腔水分計による測定を頻回に行っている術者が行った ため, 接触圧による測定值への影響が大きく現れな かったことも考えられる. 今後は口腔水分計の使用経 
験がない術者が測定を行ったときの，接触圧が測定値 に及ほす影響について検討を行う必要がある。また， 口腔乾燥を認める患者を対象とした場合の，接触圧の 測定値への影響についても検討を行う所存である.

専用センサーカバーは， $\mathrm{Ax}$ のときの水分量の平均 值と $\mathrm{Bx}$ のときの水分量の平均值の間に $0.5 \sim 0.8 \%$ の差が生じていた。腔水分計の表示値は，センサー カバーの厚み分だけカバーのない測定データよりも低 くなるとされており7)，このことから，専用カバーであっ てもカバーの厚さが異なっている可能性が考えられた。 したがって，センサーカバーによる誤差の影響を認識 したうえで結果を評価する必要があると思われる。

また, 本研究で使用した 2 個の測定器の間には測定 值に差を認めなかった. 今後はさらに多くの測定器を 対象とし, 測定器間による違いについて検討を行う所 存である。

健常成人の口腔水分量は, 舌粘膜では $30.6 \pm$ $0.3 \%$, 煩粘膜では $30.9 \pm 0.3 \%$ と一定の範囲内に収 まり，また，舌粘膜のほうが煩粘膜よりも0.3〜 $0.4 \%$ 低い值となることが明らかとなった. 内藤らの 報告9)では，20 代の被験者の口腔水分量を測定した結 果, 舌粘膜では $22.9 \pm 5.1 \%$, 煩粘膜では $22.1 \pm$ $5.2 \%$ となっており, 本研究の結果と異なっていた. 内藤らの結果で測定值が小さく，また標準偏差が大き くなったのは, 測定方法および条件によるものと思わ れる.すなわち, 測定時の口腔乾燥状態や接触圧の影 響，専用カバーの厚み分による測定值の低下などによ るものと思われる。本研究では, 測定条件の規制を 行ったために測定值のバラツキを抑えることができた ものと考えられ，口腔水分計による測定の際には測定 条件を一定にすることが必要であるといえる。

以上の結果から，口腔水分計の使用に際しては，測 定時の接触圧を適切にコントロールすることにより， 測定誤差は $1 \%$ 以下となり，また，健常成人の水分量 が一定の範囲内に収まることから，口腔水分計は誤差 を考慮したうえで結果を評価することで，安静時の口 腔乾燥状態を短時間で簡便に検査することが可能な機 器であることが示唆された。

\section{V. 結 論}

本研究では，口腔水分計の測定値に影響を与えると
考えられる接触圧, センサーカバーおよび測定器につ いて検討し,さらに, 健常成人の水分量を調べ, 以下 の結果を得た。

1. 口腔水分計の測定值は, 接触圧をメーカー指示 である約 $200 \mathrm{~g}$ にコントロールするための試作ストッ パーを付与したときには, 付与しないときよりも $0.2 〜$ $0.3 \%$ 低い值となった。

2. 口腔水分計の測定值は, 専用センサーカバーを 取り換えると 0.5〜0.8\% 異なっていた。

3. 口腔水分計の測定值は, 個々の測定器間に差は みられなかった。

4. 健常成人の口腔水分量は, 舌粘膜では平均值 $30.6 \pm 0.3 \%$, 頓粘膜では $30.9 \pm 0.3 \%$ であり, 舌粘 膜のほうが煩粘膜よりも $0.3 \sim 0.4 \%$ 低い值となった。

\section{文献}

1) Sreebny LM, Valdini A. Xerostomia. A neglectted symptom. Arch Intern Med $147:$ 1333-1337, 1987.

2）柿木保明. 年代別にみた口腔乾燥症状の発現頻度に関す る調査研究. 高齢者の口腔乾燥症と唾液物性に関する研 究 厚生労働省 - 厚生労働科学研究費補助金, 長寿科学 総合研究事業 平成 13 年度研究報告書. 19-25, 2002.

3) Peter FK, Margaret EW. A quantitative test for xerostomia-The Saxon test, an oral equivalent of the Schirmer test - . Arthritis Rheum $28: 1128-1132,1985$.

4）柿木保明. 口腔乾燥症の診断・治療・ケア. 歯界展望 $100: 366-376,2002$.

5）柿木保明. 高齢者の口腔乾燥症. デンタルダイヤ 27 ： $42-47,2002$.

6）柿木保明. 検查結果からみた口腔乾燥症の治療法選択. 㐘界展望 $103: 262-269,2004$.

7）柿木保明. 口腔水分計「モイスチャーチェッカー・ムー カス」について. 歯科評論 $727: 105-109,2003$.

8）柿木保明. 口腔乾燥症の診断基準に関する調査研究. 高 齢者の口腔乾燥症と唾液物性に関する研究 厚生労働 省・厚生労働科学研究費補助金, 長寿科学総合研究事業 平成 14 年度研究報告書. 37-41, 2003.

9) 内藤浩美, 大橋一之, 大多和 薰ほか. 口腔粘膜の湿潤 度に関する検討一正常口腔粘膜における部位による違い について一. 日粘膜誌 $9: 50-55,2003$.

著者連絡先：高橋 史

T951-8580 新潟県新潟市浜浦町 1-8

TEL : 025-267-1500

FAX : 025-267-8906

E-mail : fumichan@ngt.ndu.ac.jp 


\title{
The Usefulness of an Oral Moisture Checking Device (Moisture Checker for Mucus ${ }^{\circledR}$ )
}

\author{
Takahashi Fumi, Koji Toshiaki and Morita Osami \\ Department of Complete Denture, The Nippon Dental University School of Dentistry at Niigata
}

J Jpn Prosthodont Soc 49：283-289, 2005

\section{ABSTRACT}

Purpose : An oral moisture checking device is easy to use for the examination of oral dryness during clinical procedures. This study examined the usefulness of an oral moisture checking device.

Methods: The subjects in the examination of factors that influence the measured value of the oral moisture checking device were 16 sound adults (mean age 27.5). The subjects in the examination of measuring the moisture of sound adults were 32 adults (mean age 24.4). In the factors that influence the measured value of the device, the measuring pressure was examined by comparing the measured value with a trial stopper and without the stopper. The factor of sensor cover was examined by comparing the measured value before and after changing the sensor cover. The factor of device was examined by comparing the measured value using the two devices. The moisture of sound adults was measured at the lingual mucosa and buccal mucosa.

Results: The measured value with a trial stopper was lower by $0.2-0.3 \%$ than that without the stopper. The measured value differed before and after changing the sensor cover by $0.5-0.8 \%$. The measured value was not different among devices. The mean value of the moisture of sound adults was $30.6 \pm 0.3 \%$ at the lingual mucosa, and $30.9 \pm 0.3 \%$ at the buccal mucosa.

Conclusions : The measurement errors of the oral moisture checking device were within $1 \%$ under the condition of proper measuring pressure. Additionally, the moisture of sound adults converged toward definite values. The results of this study suggested that the oral moisture checking device is useful for the examination of xerostomia.

\section{Key words}

xerostomia, oral moisture checking device, usefulness 